\title{
Study on the Business Mode Innovation of Firms in Logistics Industry: A Case Study
}

\author{
Lan Wang \\ School of Business, Beijing Language and Culture University, Beijing, China \\ Email: im2003@163.com \\ Received 10 September 2015; accepted 25 September 2015; published 28 September 2015 \\ Copyright (C) 2015 by author and Scientific Research Publishing Inc. \\ This work is licensed under the Creative Commons Attribution International License (CC BY). \\ http://creativecommons.org/licenses/by/4.0/

(c) (i) Open Access

\begin{abstract}
In the globalization era, alliance and partner-like relationship has continued to become more and more popular among academic scholars and practical managers. The service sector plays an increasingly important role in economic development. The emergence, development and mature of productive service industry reflect the deepening of modern economic industry labor division and the complication of industrial construction, as well as the dynamic features of resource flow, value flow and knowledge flow across industries. This article elaborates elements of the business model innovation though case analysis. By analyzing macro-environment and regional environment of logistics industry development, this article elaborates how logistics firms make innovation to create new business model and summarizes three typical business models "product supplier, value-added service supplier and supply chain service supplier", which show the upgrading route of making profit from the economy scale to integrated service.
\end{abstract}

\section{Keywords}

Business Mode, Service Provider, Logistics Industry, Value Creation

\section{Introduction}

The emergence, development and mature of productive service industry reflect the deepening of modern economic industry labor division and the complication of industrial construction, as well as the dynamic features of resource flow, value flow and knowledge flow in and between industries. The logistics industry becomes one of the most important productive service industries, which exist and improve mutually with modern production system. The productive service industry, as an investment of manufacturing, is benefit for manufacturing enterprises to adapt to the changes of technology, product and producing process in the market, as well as helping manufacturing enterprises to reduce the insufficiency of ability on management, organization and information, leading to an improvement of efficacy. Since the logistics industry and other productive service industries de- 
velop and mature, they gradually become the important industries of economic development and the booster of economic competitiveness, as well as the fundamental force of industrial improvements and gross domestic profits. From the perspective of industrial revolution, logistics industry is the result of labor division based on specialization and the reform of all business parts. Production needs more general intermediates, knowledge and technology because of the complexity of production system. Since the increase of logistics needs, the logistics industry was born in labor division, becoming one of the most important parts of the industry chain [1].

\section{The Macro-Environment of Logistics Industry Development}

"The 12th Five-Year Plan" is the crucial period for China to develop from the medium term to later period in industrialization. The economic development will have many new features and trends compared to the last Five-Year Plan due to the influence from external environment, policy reform, industrialization, informatization, and urbanization. Since external needs decrease, China's economic increase will mainly depend on internal needs. A new industrialization type will be China's choice, demonstrating a combined trend with development of informatization and heavy chemical industrialization. The structure of industry will upgrade from utilizing energy raw material in the last "Five-Year Plan" to high degree of machining and technology. Meanwhile, the structure of products will transfer from production materials to consuming materials. The primary industry will have a decrease of its ratio, the percentage of the second industry will reduce after a rise (it will go up during "The 12th Five-Year Plan"), and the third industry will grow gradually. Within the industry construction, the high degree machining manufacturing will become the dominating industry while the light industry and energy raw material industry will witness declines in the proportion of national economy.

The transfer of economy development created many opportunities for logistics industry, as well as driving logistics companies to specialization and intensification. So far, China has decided to develop nine importance projects in logistics industry, including multimodal transport and transport facilities, logistics park, city delivery, bulk commodity and rural logistics, the combined development of manufacturing and logistics, the standard of logistics and the popularize of technology, platform of public logistics information, handle key problems in logistics and emergency delivery. These nine crucial projects point out the future development of logistics and the strategic concentration, offering support for the third party (logistics enterprises) in rapid development and international competition.

\section{Regional Environment Analysis}

The development of logistics industry depends on the development level of industry and the colonization of logistics industry. Several major increases in economy will become important areas in the prior development of industrial logistics. Such as:

- Beijing, Tianjin and Hebei area. The potential of logistics in this area is huge, and the location has outstanding advantages. The industrial logistics need in Beijing is large—a "three rings, five lines, several centers" situation has been formed. Tianjin has advanced domestic and international logistics, as well as a collection of logistics in the central area of city. Hebei has five logistics cities with location convenience by using harbors, developing industries, encouraging consumptions and combining traffic hubs. This area will become an important experimental area of scale development for companies in five years.

- Shenyang economic area. So far, this area has brought up a logistics industrial formation-“one circle, two area and three lines". It will implement the combined development of manufacturing and logistics, logistics channel and regional linkage, the establishing of logistics parks, the building of the third party logistics and logistics distribution system, platform of public logistics information, specialized logistics in important area and standardization of logistics and popularization of new technology in logistics. It will ensure the satisfactory development of logistics by investing in multi-channels and increasing the support of policies. This area will possibly become an important expanded area for companies in five years.

- Pearl River Delta region. This area has a good environment for logistics, and the logistics industry develops well with companies. The Pearl River Delta region has a highly intensified enterprise collection, developed transportation system, unique location of being close to Hongkong. Foshan has built up an embedded development of logistics parks and industry parks, while Guangzhou has a fundamental model of modernized delivery center. This area will become the strategy cultivation area for companies on intensification development in five years. 


\section{Main Profit Model}

Because of the deepening of industrial labor distribution, the logistics industry develops to be large-scale, specialized and intensified. It has formed following profit models:

- The supplier of products. This model is product oriented and provides one-stop "products” by implementing "Walmart model" - a scaled model that has plenty of products and high efficiency of operation, leading to low-cost profits. This model requires companies to have similar client groups and stable suppliers and a scaled size of the company itself, which could maintain the advantageous position in negotiations. The core of this model is pursuing "scale economy" [2].

- Value-added service suppliers. This model is value-added service oriented. It performs in business process to offer value-added service, making profits by modeling value-added services and the distinguishing of service innovation [3]. This model requires companies to have strong ability to offer value-added services, as well as understanding and handling the needs of clients and business process. Companies are supposed to establish stable strategic federal relationships with clients. The core of this model is pursuing "economy of scope" [4] [5].

- Supplier chain service supplier. This model is integration services oriented. At the mean time of offering one-stop supplier chain services, companies can make profits by integrating supplier chain values and the centralization of diversification expansion. This model requires companies to have independent investment rights and smooth financing channels [6]. The companies are also required to be able to penetrate and integrate in crucial parts of supplier chain by joint capital, joint operation and acquisition. This model could promote the value upgrade of the whole supplier chain at the same time of offering one-stop supplier chain services. The core of this model is pursuing "integrated economy" [7].

\section{Case Analysis-Company A}

\subsection{Company Background}

Within the ten-year development of Company A, A has established three business parts: domestic trading, international trading and industrial logistics. In these three business parts, domestic trading and international trading are the sources of sales and profits so far, while the logistics business contributes less in sales and profits. Therefore, domestic trading and international trading are the revenue and profit winners for Company A.

In the comparison of domestic trading and international trading, the domestic trading accounts for around $80 \%$ of the total revenue of Company A, while it contributes to around $70 \%$ of the total profit. The international trading, on the other hand, accounts for about $20 \%$ of the total revenue, but contributes to about $30 \%$ of the total profits. Therefore, in general, international trading makes a decent part of the profits with a small business percentage, but domestic trading stands for the opposite situation. So far, the domestic trading and international trading are the main business types in Company A, and they are the major sources for Company A's cash flow. Industrial logistics is a newly created business, and it has great potential, but it has not yet formed an available profit model. An incomplete business structure will hinder the sustainable development of Company A in the future. However, the analysis of business aims to help Company A to form a healthy combination of business, in order to support the sustainable development of the company.

Company A will pursue the improvements of total value and sustainable development. In order to achieve the goals, Company A will focus on the development of high value-added services, and it will offer comprehensive logistics solutions for clients.

Company A should use strategic reform to form a healthy business combination comprising major business, strategic business and newly created business. In five years, Company A will develop mainly on strategic business. It will transfer from "Trade zone logistics" to "Logistics trade".

The main business types of Company A include international trading and domestic trading, among which the international trading and domestic trading implement stable strategies. The focus of major business are optimizing structure, reducing costs, and developing the potential of making profits. The newly created business of Company A is industrial logistics. This business type needs to develop expansionary strategies, and the focus of this type is to expand its scale rapidly and to develop value-added services. The goal of the industrial logistics is to grow as the strategic business for Company A in five years. 


\subsection{The Development Strategy of Company A}

Company A will improve its operation methods to create new profit model, and it will improve the innovation level of services. It will transfer from products supplier to comprehensive supplier chain supplier. The company will develop the ability of original innovation, intensified innovation and the innovation on imported products. On the basis of supporting current business, the company needs to develop profitable value-added services, increase the innovation services, and improve the quality of services. The company needs to combine the specialized services and comprehensive services, and to develop both of these fields. The company needs to utilize the advantages and come over disadvantages to improve the comprehensive abilities. The company also needs to use the market resources to mainly satisfy the needs from Beijing market, and to expand constantly to the surrounding areas and the whole country. It should optimize the import and export services, the resource distribution, and grasp opportunities. Company A should also cultivate innovative talents and specialize talents to expand the client resources and collect the cash for developments. Meanwhile, Company A should attract important people by the force of cultural cohesion, gain client sources by the force of strategic alliances, and obtain cash by the force of capital operation. These methods are shown as follows:

1) Improve the ability of value-added services. The value-added services are expanded from both horizontal and vertical. Vertical value-added service is to innovate the distribution center, stock management and trading responsibilities, aiming to create high value-added services; horizontal value-added service is to increase business categories, aiming to improve the current profit model by increase value-added services [8].

To provide VMI logistics services. On the basis of improving the level of stock management, Company A can offer VMI logistics services to related enterprises. The company should deeply integrate the resources in its system and promote the interior and exterior process of the VMI stock, including delivery planning, stock planning, orders management, customs claim, resources management and moving, to provide high value-added services. The company should also complete the format of distribution centers and the function establishments, and achieve to transfer from stocking function to modern logistics center. Moreover, it should establish distribution center in areas that have collections of industrial enterprises, to achieve a logistics network and satisfy the needs of immediate delivery. In this way, Company A can provide service to firms in the industrial manufacturing field [9] [10].

Offer logistics processing services. On the basis of procurement function, the company should develop the business of logistics processing and material handling. The processing services should develop from simply parts assembly, packaging, and segmentation to services of higher levels.

Offer financing services of the supplier chain. In the model of financing warehouse operation, the company can provide custody of collateral, assessment of values, monitoring of whereabouts and credit guarantee to bridge the financing between the bank and companies. In the model of logistics bank business, the company will provide comprehensive services of financing and settlement for industrial enterprises. In the model of settlement on behalf of clients, the company will add its value by offering services of settling the loans to industrial enterprises.

2) Investments and financing. The company should accelerate the speed of cash flow, increase the utilization efficiency of capital, and support the development of business financially.

The company should increase the proportion of large credit financing. The company should keep the percentages of bank loan financing and financial holding loans. It ought to strengthen the relationships with financial institutes and superior departments, in order to increase the loan limit and fulfill the needs for expansion on all business. It should develop the financing models of diversified small amount credits to meet emergencies. The company should also adopt methods such as factoring financing, credit loan financing, speeding the payback period of receivable accounts and improving the turnover rate of stocking, to obtain cash for short-term emergencies and solve capital problems. The company should consider collecting big amount of capital by listing on IPO. Compared to the domestic backdoor listing and listing overseas, the suitable listing method is to list through IPO and finance.

3) Exploit diversified human resource management. Based on the principle of "full training and key training", the company should improve the knowledge quality of staff to ensure the fast development of the company. The urgently needed talents should be the first ones for training to fulfill the need for strategic development; the frontline workers should be trained to adapt the need of high production; the management staff should be trained to improve the management efficiency. The company ought to establish its cultures actively and build up a sa- 
tisfying working environment to attract and retain talents. A good working environment can motivate staff's innovation, increase the sense of belonging, and form the team spirit. The company should establish effective incentive mechanism and competing mechanism, to attract more logistics talents by same values and goals. The company should also establish a position ability model that is connected with performance, and assess logistics talents by diversified and multi-angle assessment models. In addition, it should use behavior assessment methods to value the characteristics of employees, ensuring that the employee's personality is suitable for the job. Meanwhile, the company should establish incentive compensation mechanism to attract logistics talents by ensuring the income differences and differentiate incomes reasonably. The income amount should depend on the economic performance and be dynamic. The company should also establish a compensation system that the incomes of employees depend on company's performance and personal performance. Also, the company ought to guarantee the effectiveness of distribution, ensuring the interior fairness and exterior competitiveness. At last, the company should establish a scientific performance assessing benchmark system and a market oriented distribution system, making sure that the compensation of the company is competitive in the market.

In the strategic transformation period, Company A focused on service innovation and improved the operational mechanism to maintain the overall level of competitiveness and the strategic objectives. Company A now changes the business mode as integrated logistics service provider and can meet all the diverse and dynamic needs of industrial enterprises.

\section{Acknowledgements}

This research is supported by BLCU (Beijing Language and Culture University) supported project (supported by the Fundamental Research Funds for the Central Universities) (Approval Number: 15YJ0404). I appreciate the support from BLCU (Beijing Language and Culture University) Business School supported project (supported by the Fundamental Research Funds for the Central Universities) (Approval Number: 15YJ0404). I also appreciate the support from Beijing supporting Central University joint project-Young Talent Plan (Project No. YETP0880).

\section{References}

[1] Sirmon, D.G., Hitt, M.A. and Ireland, R.D. (2007) Managing Firm Resources in Dynamic Environments to Create Value: Looking inside the Black Box. Academy of Management Review, 32, 273-292. http://dx.doi.org/10.5465/AMR.2007.23466005

[2] Skaates, M.A. and Seppanen, V. (2002) Managing Relationship-Driven Competence Dynamics in Professional Service Organizations. European Management Journal, 20, 430-437. http://dx.doi.org/10.1016/S0263-2373(02)00066-X

[3] Skipworth, H. and Harrison, A. (2004) Implications of Form Postponement to Manufacturing: A Case Study. International Journal of Production Research, 42, 2063-2081. http://dx.doi.org/10.1080/00207540410001661373

[4] Sorensen, J.B. and Stuart, T.E. (2000) Aging, Obsolescence and Organizational Innovation. Administrative Science Quarterly, 45, 81-113. http://dx.doi.org/10.2307/2666980

[5] Slater, S.F. and Narver, J.C. (1995) Market Organization and the Learning Organization. Journal of Marketing, 59, 63-74. http://dx.doi.org/10.2307/1252120

[6] Stuart, T. (1998) Network Positions and Propensities to Collaborate: An Investigation of Strategic Alliance Formation in a High-Technology Industry. Administrative Science Quarterly, 43, 668-698. http://dx.doi.org/10.2307/2393679

[7] Tiwana, A. (2008) Do Bridging Ties Complement Strong Ties? An Empirical Examination of Alliance Ambedexiterity. Strategic Management Journal, 29, 251-272. http://dx.doi.org/10.1002/smj.666

[8] Uzzi, B. (1997) Social Structure and Competition in Interfirm Networks: The Paradox of Embeddedness. Administrative Science Quarterly, 42, 35-67. http://dx.doi.org/10.2307/2393808

[9] Vickery, S., Calantone, R. and Dröge, C. (1999) Supply Chain Flexibility: An Empirical Study. The Journal of Supply Chain Management, 35, 16-24. http://dx.doi.org/10.1111/j.1745-493X.1999.tb00058.x

[10] Varadarajan, P.R. and Cunningham, M.H. (1995) Strategic Alliances: A Synthesis of Conceptual Foundations. Journal of the Academy of Marketing Science, 23, 282-296. http://dx.doi.org/10.1177/009207039502300408 